\title{
41. 食料需要モデルを利用した黄河流域の農業用水消費に関する研究 Study on Agricultural Water Consumption by Food Demand Model in Yellow River Basin
}

園田益史*·大西暁生*·白川章博*·井村秀文* Masufumi SONODA, Akio ONISHI, Akihiro SHIRAKAWA and Hidefumi IMURA

\begin{abstract}
Yellow River basin faces water shortage. Therefore, change of water use by replacing food supply may affect water supply and demand balance. Food production in the basin provides food demand inside and outside of the basin through the transportation. Firstly, this study estimated food supply under change of eating habits, which is based on supply and demand proportion of food balance of year 2000 in China. Secondary, additional water use amount by change of food supply was estimated. Demand elasticity in each food item such as grain, vegetable, edible oil, meat, eggs, fisheries product, sugar, was calculated by using the Almost Ideal Demand System. Also, food transportation amount based on food surplus and deficit was calculated by transportation model. As a result in the case of income increase wheat demand in the basin and pig meat demand in out-basin have impacts on basin water duty. And in case of cereal price decline wheat and maze demand in the in and out of basin have more impacts on the water duty.
\end{abstract}

KEYWORDS; Yellow River basin, agricultural water, food demand, Almost Ideal Demand System

\section{1 はじめに}

中国黄河流域では, 進展する経済発展に伴って水資源の不足が顕在化している. 1990 年代には河道の水が干上がっ てしまう断流と呼ばれる現象が, 頻繁に観測され, 流域の生態系や環境への影響が危惧された. 流域の水消費を産業セク ターごとにみると, 農業は全体の $70 \%$ 用水を消費しており, とくに穀物生産に投じられる灌溉用水量が水収支に与える 影響が大きい. 現在, 中国国内の輸送網は急速に整備されてきており, 流域で生産された農産物は, 域内の食料需要を 満たすばかりでなく, 輸送を通じて他地域の需要を満たしている. すなわち, 流域の農業用水の総量に, 流域内および域 外の食料需要が影響を及ぼしていると考えられる. 国内の食料品の需要に着目すると, 所得の増大に伴って, 1990 年代 後半から肉類や水産物, 野菜などの副食品の需要が高まっている ${ }^{1)}$. とくに, 肉類の消費の増加は, 飼料用の穀物の間接 的な消費量を増大させる.このため自地域からの飼料穀物の調達割合が大きい食肉生産地では, 水消費量が増大寸る結 果となる. 黄河流域内では, 山東省や河南省の食料生産量が大きく, 流域内の他省および流域外の地域への食料の供給 元となっている. 本研究は, 以上のような食料需要と供給地の水消費との関係に着 目し, 中国全土の食料需要が, 黄河流域の用水消費に与える影響を考察することを 目的とする. 食料需要の分析には, 需要体系モデルの1つである Almost Ideal Demand System を用い, 家計における食料品目の需要分析を行っている.

\section{2 分析の方法}

図-1 に, 本研究の分析の流れを示す. 分析では, はじめに, 中国国内の食料品 の空間的分布を把握し, 生産量とともに, 地域の食料の余剩量および不足量を推計 する. 次に, 都市と農村の別に, 消費品目の価格情報と支出額から, 食料需要の弾 性值を求める. 本研究では, 中国の統計書における, 城鎮および農村居民にあたる 值を, それぞれ都市部および農村部の統計值として扱う. さらに各省で求めた食料 の余剩量と不足量と, 国内の主要な輸送経路より, 省間の移送量と移送方向を把握 する. 最後に 2000 年において, 食料の消費分布と, 先に求めた省間の移送経路と

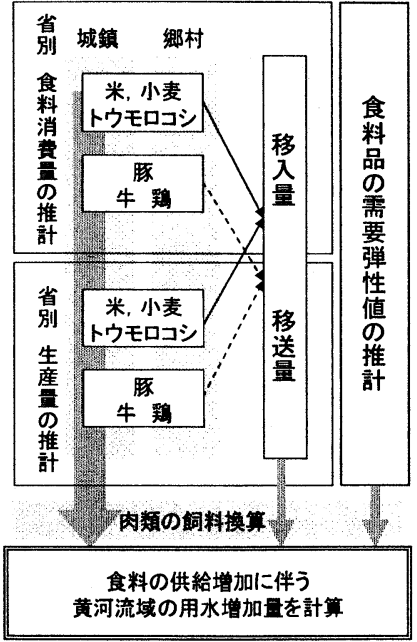

図-1 分析の流れ

*名古屋大学大学院 環境学研究科 都市環境学専攻 Graduate School of Environmental Studies, Nagoya University, Furo-cho,

Chikusa-ku, Nagoya City, Japan 464-8601. 
移送量の比率を仮定し, 食料需要の変化が, 黄河流域の水消費に与える影響を品目別に計算する. 食料需要の変化の シナリオは, 所得または穀物価格の変化に基づいている. 各分析の具体的な方法について以下に示す.

\section{1 食料消費と生産の空間分布}

米, 小麦, トウモロコシおよび豚肉, 牛肉, 鶏肉について, 2000 年の消費分布を把握する. ここでの方法は, 中谷 ${ }^{2}$ の方 法を参考としている. 中国全土の品目の総消費量については, FAO ${ }^{3)}$ の值に従うものとし, 中国統計年鑑にある省別の $1 人$ 当たり消費などから, 各省内の消費量を推計している. はじめに CIESIN ${ }^{4}$ にある, 都市と農村の 1 人当たり穀物消費量の 比率および中国粮食供求: 調查与分析 ${ }^{5}$ の農村 1 人当たりの消費量加, 各省の 1 人当たり穀物消費量 $\mathrm{U}_{\mathrm{i}, \mathrm{j}, \mathrm{k}}$ を求める. $\mathrm{i}$ は 該当の省, $\mathrm{j}$ は都市または農村の区分, $\mathrm{k}$ は品目を示寸. 品目は米, 小麦, トウモロコシを対象としている. 省 $\mathrm{i}$ の都市およ び農村人口 $P_{i, u}, P_{i, r}$ より, 各区分の消費量の割合 $S_{i, j, k}$ を式(1)に示す. 人口のデータは, 中国統計年鑑のおよび中国農業年 鑑》の值を用いた. $\mathrm{S}_{\mathrm{i}, \mathrm{j}, \mathrm{k}}$ を FAO の総消費量 $\mathrm{Q}_{\mathrm{FAO}, \mathrm{k}}$ に乗じ, 各消費量を式(2)のように合計することにより, 省 $\mathrm{i}$ の品目 $\mathrm{k}$ の消 費量 $\mathrm{Q}_{\mathrm{i}, \mathrm{k}}$ を求めた.

$S_{i, j, k}=U_{i, j, k} P_{i, j} / \sum_{i} \sum_{j} U_{i, j, k} P_{i, j} \quad$ (1) $\quad Q_{i, k}=Q_{F A O, k}\left(S_{i, u, k}+S_{i, r, k}\right)$

トウモロコシについては, 人の食料にあたる消費量に, 家畜飼料向けの消費量を加えて, 省単位の消費量とする. 飼料 の消費量の計算は, 肉類の生産量に飼料換算倸数 ${ }^{8)}$ を乗じることで計算した.

\section{2 食料需要の分析}

需要関数の推定において, 予算制約といった需要理論が求める条件を組み込んだ上で, 需要関数の推定を行うことを 可能にしたのが, 需要体系モデルである. 本研究では, 需要体系モデルに属し, 家計の予算制約を適切に表現すること が可能である Almost Ideal Demand System)(以下 AIDS と記す. ) を用いた.

\section{(A) Almost Ideal Demand System}

式(3)から(9)に AIDS の定式を示す.

$w_{i}=\alpha_{i}+\beta_{i} \ln (y / P)+\sum_{j} \gamma_{i j} \ln p_{j} \quad \forall i \quad$ (3) $\quad \ln P=\alpha_{0}+\sum_{i} \alpha_{i} \ln p_{i}+0.5 \sum_{i} \Sigma_{j} \gamma_{i j} \ln p_{i} \ln p_{j}$

収支均等: $\sum_{i} \alpha_{i}=1 \quad \sum_{i} \beta_{i}=0 \quad \sum_{i} \gamma_{i j}=0 \quad \forall j(5) \quad$ 同次性: $\quad \sum_{j} \gamma_{i j}=0 \quad \forall i$

対象性: $\quad \gamma_{i j}=\gamma_{j i} \quad \forall i, j$

需要弾力性: $\quad \eta_{i}=1+\beta_{i} / w_{i} \quad \forall i \quad \varepsilon_{i j}=-\delta_{i j}+\gamma_{i j} / w_{i}-\left(\beta_{i} / w_{i}\right)\left(\alpha_{j}+\sum_{k} \gamma_{j k} \ln p_{k}\right) \quad \forall i, j$

ここで, 定数および変数の表記は以下の通りである.

$\mathrm{y}$ :食料支出 $\mathrm{p}_{\mathrm{i}}$ : 財 $\mathrm{i}$ の価格 $\mathrm{p}_{\mathrm{i}}$ を第 $\mathrm{i}$ 成分とする価格ベクトル

$\mathbf{w}_{\mathrm{i}=\mathrm{i}} \mathbf{q}_{\mathrm{i}} / \mathrm{y}$ :財 $\mathbf{i}$ の支出比率 $\quad \eta_{\mathrm{i}}=\partial \ln \mathrm{q}_{\mathrm{i}} / \partial \operatorname{lny}$ :所得弾力性 $\quad \varepsilon_{\mathrm{i}, \mathrm{j}}=\partial \operatorname{lnqi} / \partial \operatorname{lnpj}:$ Marshall の価格弾力性 $\varepsilon_{\mathrm{i}, \mathrm{j}}{ }^{*}=\partial \operatorname{lnh}_{\mathrm{i}} / \partial \ln _{\mathrm{j}}=\varepsilon_{\mathrm{i}, \mathrm{j}}+\mathrm{w}_{\mathrm{j}} \eta_{\mathrm{j}}:$ Hicks の価格弾力性

\section{(B) 食料需要の分析}

AIDS 利用して, 1996 年から 2002 年の期間を対象とし, 中国国内の食料需要を分析する. 分析では, 城鎮と農村別に 食料品目の需要弾性值を計測する. 価格および支出データは, 中国統計年鑑 ${ }^{6)}$ 記載の都市または農村区分別の值を用 いる. データの久損の多い西蔵自治区を除いた全土 30 の省・自治区の時系列データをパネルデータセットとして用いて いる. 計測は, はじめに食料品を含めた生活品目全体に対して行い, 1段階目の需要弾性值を求める. 次に, この食料品 の需要弾性值に基づき, 穀物, 肉類といった内訳の弾性値を計測した. 表-1に分析の対象とした品目を示す.

表-1 需要分析の対象品目

\begin{tabular}{|c|c|c|c|c|c|c|c|}
\hline 第1段擆 䂥测 & 食料 & 被服 & 住宅 & 家庭用品 & 交通 & 文化教育 & 医療保険 \\
\hline 第2段鰧 計湖 & 穀物 & 野菜 & 油脂類 & 肉類 & 卵類 & 水産物 & 糖類 \\
\hline
\end{tabular}




\section{3 食料輸送モデル}

食料消費と生産の空間分布の推計結果を基にし, 輸送モデルを用いて, 2000 年時点の省間の食料輸送経路および輸 送量を推計する. 国土の広い中国では, 食料品目毎の生産の空間分布がそれぞれに異なり, 各地の消費量と生産量には 需給の不均衡がみられる. 輸送モデルでは, この需給の不均衡が輸送によって補われているものと考える. 食料 $\mathrm{k}$ の省 $\mathrm{i}$ から省 $\mathrm{j} へ の$ 移送量を $\mathrm{X}_{\mathrm{i}, \mathrm{j}, \mathrm{k}}$ しし， $\mathrm{C}_{\mathrm{i}, \mathrm{j}}$ を両省の移送距離とする. ここで, 移送量と輸送距離の積を輸送量 $\mathrm{T}_{\mathrm{i}, \mathrm{j}, \mathrm{k}}$ と定義し, 国内 の総輸送量を最小化する輸送パターンが選択されるものとする.これを目的関数として式(10)のように示す.

$$
\min T_{k}=\sum_{i=1}^{p} \sum_{j=1}^{q} C_{i, j} X_{i, j, k}
$$

国内の食料輸送には, 鉄道のほか, 幹線道路, 河川・海運の利用もされているが, 鉄道軌道と幹線道路の経路は, 近し いものと考え, 鉄道距離の利用によって代替する. 鉄道距離として, 中国列車主要駅間距離表 ${ }^{10)}$ の経路・值を用いた. 目 的関数に各省の食料余剩量 $\mathrm{A} i$ および不足量 $\mathrm{Bj}$ を示寸式(11), (12)の制約条件を加えて, 最小化を行う. $\mathrm{D}_{\mathrm{i}}, \mathrm{D}_{\mathrm{j}}$ はそれぞれ 食料輸出量と在庫の増加量の和および食料輸入量と在庫の減少量の和を示す.

$$
\sum_{i=1}^{q} X_{i, j, k}+D_{i}=A_{i}(i=1,2, \ldots, p) \quad \text { (11) } \quad \sum_{i=1}^{p} X_{i, j, k}+D_{j}=B_{j}(j=1,2, \ldots, q)
$$

\section{4 食料需要が流域の水消費に与える影響}

経済の成長に伴う食料需要の増加は, 供給に必要な用水量の増大をもたらす.ここでの分析では, 一定率の所得増加 を仮定して, 食料の供給増加量を計算する. 次に, 食料の供給増加に伴い, 流域で新たに必要となる用水量を計算する.

\section{（A）食料の供給増加量の推計方法}

食料消費と生産の空間分布, および食料輸送モデルで求めた 2000 年の食料需給状況の下で, 一定率の所得増加のシ ナリオを導入する. 所得の増加率は $1 \%$ とする.この場合の食料需要の変化を, 先に求めた弾性值功計算し, 供給増加 量を求める. 需要増加量は, 省内の生産または移入量の増加によって補われるものとする. また, 設定する所得増加率を 小さく取り, 需要の増加量は小さく, 国全体の輸入量の増減には影響しないものとする. はじめに式(13)のように, 品目の 需要増加量を所得および価格弾性值を用い, 計算する. 現在の各省の城鎮および農村の人口は変化しないものとして, 推計した食料消費量を使用している. 所得弾性値には, 城鎮および農村別の值を用いる.

$$
\Delta D_{i, m, k}=Q_{i, m, k} I_{r a t e} \eta_{m, k}
$$

$\triangle \mathrm{D}_{\mathrm{i}, \mathrm{m}, \mathrm{k}}$ : 省 $\mathrm{i}$ 世帯区分 $\mathrm{m}$ (城鎮 $\mathbf{u}$ または農村 $\mathbf{r}$ )の品目 $\mathbf{k}$ の需要増加量 $I_{\text {rate }}$ : 所得増加率 $\eta_{\mathrm{m}, \mathrm{k}}$ :世帯区分 $\mathrm{m}$ の品目 $\mathbf{k}$ の所得弾性値

得られした都市または農村の世帯区分別の需要増加量を合計し,省 $\mathbf{i}$ の需要増加量を求める. 不足省における移入の増 加量については, 式(14)のように計算する. 不足省においては, 2000 年時点において, 省内生産量が需要量を下回って いる現状を考慮し, 需要の増加量 $\Delta \mathrm{D}_{\mathrm{j}, \mathrm{m}, \mathrm{k}}$ を移入の増加によって満たすものと考える.

$$
\sum_{i} \Delta T_{i, j, k}=\Delta D_{j, m, k} \quad \Delta \mathrm{T}_{\mathrm{i}, \mathrm{j}, \mathrm{k}} \text { 余剩省 } \mathrm{i} \text { から不足省 } \mathrm{j} \text { への品目 } \mathrm{k} \text { の移出量 }
$$

省内の肉類生産に用いられる飼料分のトウモロコシについては, 豚肉, 牛肉, 鷄肉の生産増加量を式(13), (14)を用い て求め,この值を飼料の換算ベースに直すことにより求める.

\section{（B）用水增加量の推計方法}

食料の供給増加量に基づき, 生産に必要となる用水の増加量を推計する. 推計は, 黄河流域の各省を単位として行う. ここで, 用水の消費は, すべて灌溉用水の消費であるとする. 穀物の供給に伴う用水量の推計においてはまず, 供給増加 量に伴って必要となる耕地面積を, 面積当たりの品目生産量を用いて求める.この面積に省内の流域面積の割合を乗じる 
ことで, 流域内に属する耕地面積に換算する. 次に, この耕地面積のうち, 灌沅面積を, 省の灌溉面積の割合 (以下, 灌洦 率と記す. )に基づいて計算する.これに灌溉面積当たりの年間の灌溉用水量(以下, 灌溉定数と記す.)を乗じることによ り, 省内の用水の増加量を求める. 式(15)に推計式を示す. なお, 他省の肉類の需要を満たすため, 省内の家畜に供給さ れる飼料吊ロコシに必要な用水量は, 該当する肉類の需要に伴う用水量として計上する.これにより, 肉類と飼料の卜ウ モロコシの需要に伴う用水の重複の計上を防ぐ.

$$
\Delta W_{i, k}=\frac{\Delta D_{i, k}}{C_{i, k}} \alpha_{i} \beta_{i} w_{i, k}
$$

$\Delta \mathbf{W}_{\mathrm{i}, \mathrm{k}}$ :省 $\mathbf{i}$ における品目 $\mathbf{k}$ の供給増加に伴う用水量 $\left(\mathrm{m}^{3}\right)$

$\mathrm{C}_{\mathrm{i}, \mathrm{k}}$ : 省 $\mathrm{i}$ における品目 $\mathrm{k}$ 単位耕地面積当たり生産量 $(\mathrm{t} / \mathrm{ha}) \quad \alpha_{\mathrm{i}}$ : 省 $\mathrm{i}$ の流域面積の割合 $(\%)$

$\beta_{\mathrm{i}}$ : 省 $\mathbf{i}$ の灌溉面積率 $(\%) \quad \mathrm{w}_{\mathrm{i}, \mathrm{k}}$ : 省 $\mathrm{i}$ の品目 $\mathrm{k}$ の灌溉定数 $\left(\mathrm{m}^{3} / \mathrm{ha}\right)$

省の面積当たり生産量は, 統計年鑑の種蒔面積(作付面積)および生産量から計算している. 灌溉率および灌溉定数は, 中国可持続発展水資源戦略研究報告集 ${ }^{11)}$ および中国水資源公報 ${ }^{12)}$ の值を用いた.

\section{3 分析の結果}

\section{1 食料需要の分析結果}

表-2, 3 に, 食料品目について, 都市部と農村部において, 推計した所得弾性值および価格弾性值を示寸.

表-2 都市部 食料品目の所得弾性値

\begin{tabular}{|c|c|c|c|c|c|c|c|c|c|}
\hline \multirow{2}{*}{$\begin{array}{c}\text { 品目 } \\
\text { i }\end{array}$} & \multirow{2}{*}{$\begin{array}{c}\text { 所得弾性值 } \\
\text { ei }\end{array}$} & \multicolumn{7}{|c|}{ Marshall の価格弾性値 } & \multirow{2}{*}{$\begin{array}{c}\text { 決定係数 } \\
\mathrm{R} 2 \\
\end{array}$} \\
\hline & & $\eta_{\mathrm{in}}$ & $\eta_{\mathrm{i} 2}$ & $\eta_{\mathrm{i} 3}$ & $\eta_{i 4}$ & $\eta_{\text {is }}$ & $\eta_{i 6}$ & $\eta_{\mathrm{i} 7}$ & \\
\hline 1. 縠物 & 0.203 & $\begin{array}{l}-0.937 \\
(0.31)\end{array}$ & $\begin{array}{l}0.214 \\
(2.64)\end{array}$ & $\begin{array}{l}0.276 \\
(4.17)\end{array}$ & $\begin{array}{l}-0.015 \\
(-.010)\end{array}$ & $\begin{array}{l}-0.060 \\
(-1.15)\end{array}$ & $\begin{array}{l}0.438 \\
(4.08)\end{array}$ & $\begin{array}{l}-0.906 \\
(-6.75)\end{array}$ & 0.728 \\
\hline 2. 野菜 & 0.708 & $\begin{array}{l}0.241 \\
(2.64)\end{array}$ & $\begin{array}{l}-0.562 \\
(4.50)\end{array}$ & $\begin{array}{l}0.040 \\
(0.69)\end{array}$ & $\begin{array}{l}-0.168 \\
(-1.75)\end{array}$ & $\begin{array}{l}0.028 \\
(0.54)\end{array}$ & $\begin{array}{l}-0.149 \\
(-1.45)\end{array}$ & $\begin{array}{l}-0.426 \\
(-3.75)\end{array}$ & 0.445 \\
\hline 3. 油脂類 & 0.458 & $\begin{array}{l}0.872 \\
(4.17)\end{array}$ & $\begin{array}{l}0.112 \\
(0.69)\end{array}$ & $\begin{array}{r}-0.362 \\
(3.52)\end{array}$ & $\begin{array}{l}1.192 \\
(5.58)\end{array}$ & $\begin{array}{l}-0.457 \\
(-3.98)\end{array}$ & $\begin{array}{l}-1.800 \\
(-8.40)\end{array}$ & $\begin{array}{l}-0.551 \\
(-2.16)\end{array}$ & 0.411 \\
\hline 4. 肉類 & 1.172 & $\begin{array}{l}-0.010 \\
(-.010)\end{array}$ & $\begin{array}{l}-0.081 \\
(-1.75)\end{array}$ & $\begin{array}{l}0.202 \\
(5.58)\end{array}$ & $\begin{array}{l}-1.090 \\
(-0.73)\end{array}$ & $\begin{array}{l}0.244 \\
(7.90)\end{array}$ & $\begin{array}{l}-0.589 \\
(-7.34)\end{array}$ & $\begin{array}{l}0.323 \\
(3.30)\end{array}$ & 0.296 \\
\hline 5. 卵類 & 0.346 & $\begin{array}{l}-0.211 \\
(-1.15)\end{array}$ & $\begin{array}{l}0.087 \\
(0.54)\end{array}$ & $\begin{array}{l}-0.511 \\
(-3.98)\end{array}$ & $\begin{array}{l}1.612 \\
(7.90)\end{array}$ & $\begin{array}{l}-1.192 \\
(-1.26)\end{array}$ & $\begin{array}{l}-0.225 \\
(-1.03)\end{array}$ & $\begin{array}{l}-0.553 \\
(-2.17)\end{array}$ & 0.57 \\
\hline 6. 水産物 & 2.781 & $\begin{array}{l}0.813 \\
(4.08)\end{array}$ & $\begin{array}{l}-0.250 \\
(-1.45)\end{array}$ & $\begin{array}{l}-1.065 \\
(-8.40)\end{array}$ & $\begin{array}{l}-2.059 \\
(-7.34)\end{array}$ & $\begin{array}{l}-0.120 \\
(-1.03)\end{array}$ & $\begin{array}{l}\mathbf{0 . 3 7 0} \\
(3.99)\end{array}$ & $\begin{array}{l}1.292 \\
(4.62)\end{array}$ & 0.733 \\
\hline 7. 糖類 & 1.712 & $\begin{array}{l}-4.633 \\
(-6.75) \\
\end{array}$ & $\begin{array}{l}-1.928 \\
(-3.75)\end{array}$ & $\begin{array}{l}-0.890 \\
(-2.16) \\
\end{array}$ & $\begin{array}{l}3.069 \\
(3.30) \\
\end{array}$ & $\begin{array}{r}-0.799 \\
(-2.17) \\
\end{array}$ & $\begin{array}{r}3.530 \\
(4.62)\end{array}$ & $\begin{array}{r}\mathbf{0 . 6 4 3} \\
(1.32) \\
\end{array}$ & \\
\hline
\end{tabular}

表-3 農村部 食料品目の所得弾性値

\begin{tabular}{|c|c|c|c|c|c|c|c|c|c|}
\hline \multirow{2}{*}{$\begin{array}{c}\text { 品目 } \\
\text { i }\end{array}$} & \multirow{2}{*}{$\begin{array}{c}\text { 所得弾性值 } \\
\text { ei }\end{array}$} & \multicolumn{7}{|c|}{ Marshall の価格弾性值 } & \multirow{2}{*}{$\begin{array}{c}\text { 決定係数 } \\
\mathrm{R} 2 \\
\end{array}$} \\
\hline & & $\eta_{\mathrm{ij}}$ & $\eta_{i 2}$ & $\eta_{\mathrm{i} 3}$ & $\eta_{\mathrm{i} 4}$ & $\eta_{\mathrm{is}}$ & $\eta_{i 6}$ & $\eta_{\mathrm{iz}}$ & \\
\hline 1. 款物 & 0.564 & $\begin{array}{l}-\mathbf{- 0 . 7 8 5} \\
(5.05)\end{array}$ & $\begin{array}{c}-0.14 \\
(-3.63)\end{array}$ & $\begin{array}{c}-0.186 \\
(-36.51)\end{array}$ & $\begin{array}{l}0.005 \\
(0.53)\end{array}$ & $\begin{array}{l}-0.021 \\
(-3.07)\end{array}$ & $\begin{array}{l}-0.001 \\
(0.02)\end{array}$ & $\begin{array}{c}0.131 \\
(7.20)\end{array}$ & 0.514 \\
\hline 2. 野菜 & 2.127 & $\begin{array}{l}-0.343 \\
(-3.63)\end{array}$ & $\begin{array}{l}-1.595 \\
(-2.28)\end{array}$ & $\begin{array}{l}0.247 \\
(4.40)\end{array}$ & $\begin{array}{r}-0.066 \\
(-0.80)\end{array}$ & $\begin{array}{l}0.294 \\
(5.00)\end{array}$ & $\begin{array}{l}0.319 \\
(3.69)\end{array}$ & $\begin{array}{c}0.134 \\
(0.81)\end{array}$ & 0.444 \\
\hline 3. 油脂類 & 0.723 & $\begin{array}{c}-6.175 \\
(-36.51)\end{array}$ & $\begin{array}{l}3.437 \\
(4.40)\end{array}$ & $\begin{array}{l}0.626 \\
(3.23)\end{array}$ & $\begin{array}{l}1.037 \\
(3.51)\end{array}$ & $\begin{array}{l}-0.786 \\
(-2.11)\end{array}$ & $\begin{array}{r}0.506 \\
(1.30)\end{array}$ & $\begin{array}{r}0.357 \\
(0.67)\end{array}$ & 0.937 \\
\hline 4. 肉類 & 1.637 & $\begin{array}{l}0.076 \\
(0.53)\end{array}$ & $\begin{array}{l}-0.427 \\
(-0.80)\end{array}$ & $\begin{array}{l}0.481 \\
(3.51)\end{array}$ & $\begin{array}{l}-1.181 \\
(-0.56)\end{array}$ & $\begin{array}{l}0.089 \\
(0.54)\end{array}$ & $\begin{array}{l}-0.347 \\
(-1.82)\end{array}$ & $\begin{array}{c}0.301 \\
(0.79)\end{array}$ & -0.0171 \\
\hline 5. 卵類 & 0.451 & $\begin{array}{l}-1.142 \\
(-3.07)\end{array}$ & $\begin{array}{c}6.75 \\
(5.00)\end{array}$ & $\begin{array}{l}-1.296 \\
(-2.11)\end{array}$ & $\begin{array}{l}0.318 \\
(0.54)\end{array}$ & $\begin{array}{c}-0.603 \\
(0.52)\end{array}$ & $\begin{array}{l}-2.196 \\
(-3.47)\end{array}$ & $\begin{array}{l}-2.826 \\
(-2.98)\end{array}$ & 0.309 \\
\hline 6. 水産物 & 2.524 & $\begin{array}{r}-0.046 \\
(0.02)\end{array}$ & $\begin{array}{l}7.859 \\
(3.69)\end{array}$ & $\begin{array}{l}0.897 \\
(1.30)\end{array}$ & $\begin{array}{l}-1.326 \\
(-1.82)\end{array}$ & $\begin{array}{l}-2.363 \\
(-3.47)\end{array}$ & $\begin{array}{l}\mathbf{- 8 . 2 5 6} \\
(-5.90)\end{array}$ & $\begin{array}{c}2.22 \\
(1.69)\end{array}$ & 0.147 \\
\hline 7. 糖類 & 13.794 & $\begin{array}{c}22.6 \\
(7.20)\end{array}$ & $\begin{array}{r}9.692 \\
(0.81) \\
\end{array}$ & $\begin{array}{r}1.856 \\
(0.67) \\
\end{array}$ & $\begin{array}{r}3.374 \\
(0.79) \\
\end{array}$ & $\begin{array}{r}-8.886 \\
(-2.98)\end{array}$ & $\begin{array}{r}6.49 \\
(1.69) \\
\end{array}$ & $\begin{array}{r}35.977 \\
(-3.26)\end{array}$ & \\
\hline
\end{tabular}

所得弾性値を城鎮と農村で比較すると, 農村の值が水産物以外でより大きい結果となった. 価格弾性值の下の括弧内 
の值は $\mathrm{t}$ 值を示している. 所得増加による食料品の需要の増加は, 近年では農村部の方が大きく顕れている. 殼物の所得 弾性值は他品目と比較して小さく, 都市部ではその傾向が顥著に見られている. 一方, 肉類と水産物の需要は, 城鎮部と 農村部で共に大きい. また農村部では, 野菜と糖類の需要が大きい. 価格弾性值をみると, 穀物では, 農村部より都市部で 価格変化による需要への影響が大きい. 肉類の価格変化の影響は同じ程度であるが, 水産物と野菜では, 農村部で価格 が低下した場合の需要増加が大きいことが伺える.

\section{2 食料軴送モデル}

図-2，3，4に2000年において, 推計された米, 小麦, トウモロコシの移送量および移送方向を示す. 同様に豚肉, 牛肉, 鶏肉についても移送経路を求めた. ここで求められた移送量・移送経路に基づき, 次節の用水量消費量の分析を行う.

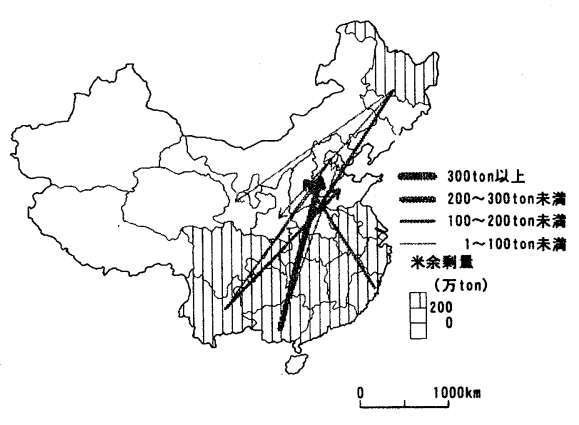

図-2 米の移送量の推計 2000 年

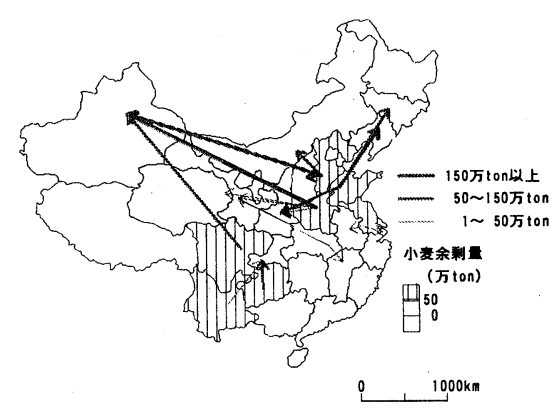

図-3 小麦の移送量の推計 2000 年

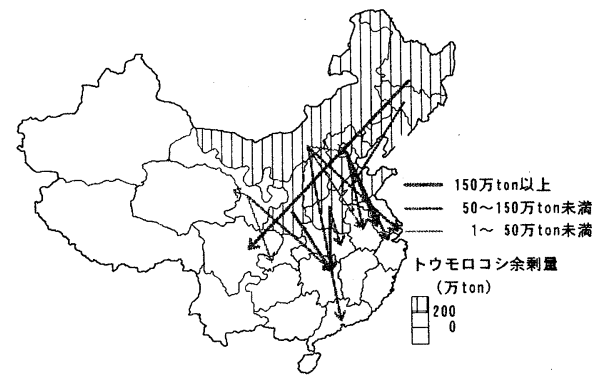

図-4 トウモロコシの移送量の推計 2000 年

\section{3 食料需要が流域の水消費に与える影響}

所得の増加による全土の食料需要の増加が, 黄河流域の水消費量に与える結果を示す. 所得の増加率は $1 \%$ としてい る. 図-5, 6, 7 に米, 小麦, トウモロコシの需要増加に伴う用水増加量を示す.

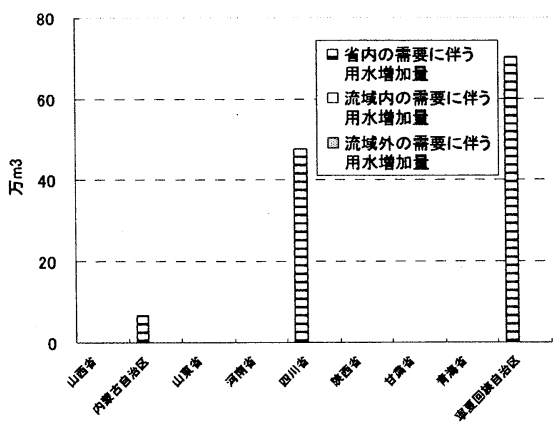

図-5 米の需要に伴う用水増加量 (所得増加率 1\%)

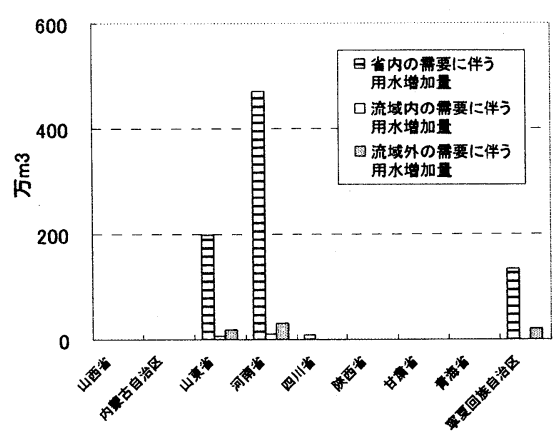

図-6 小麦の需要に伴う用水増加量 (所得増加率 $1 \%$ )

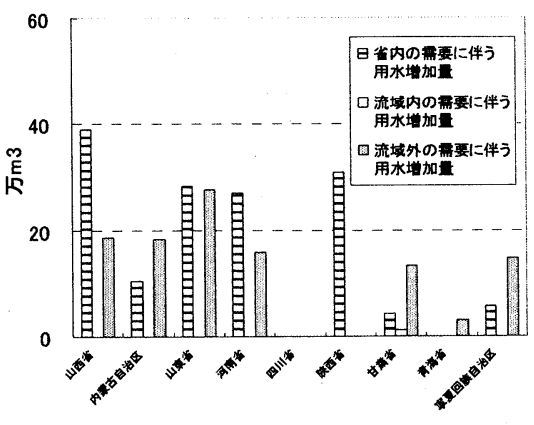

図-7 トウモロコシの需要に伴う 用水増加量(所得増加率 $1 \%$ )

次に, 図-8, 9 に豚肉, 牛肉の需要増加に伴う用水増加量を示す. 鶏肉についても計算を行ったが, 他の肉類に比べ用 水増加量への影響はわずかであったため, 示していない.

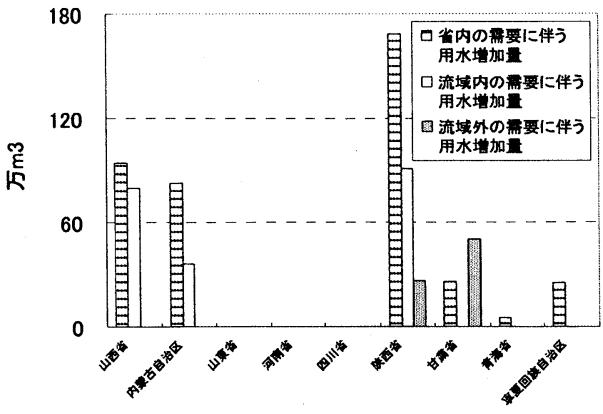

図-8 豚肉の需要に伴う用水増加量 （所得増加率 $1 \%$ )

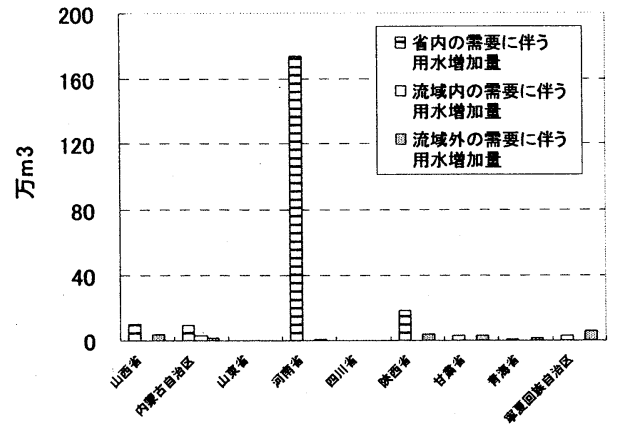

図-9 牛肉の需要に伴う用水増加量 （所得増加率 1\%) 
図-10 に流域で合計した用水増加量を示す. 品目毎の増加 量を比較してみると, 小麦, 豚肉, 牛肉の順に大きい. 流域外 の需要に伴う増加量はトウモロコシが最も大きい結果となった。

\section{4 結論}

食料需要が流域の水消費に与える影響について, 結論を以 下に示寸. 全土の所得増加率を $1 \%$ とした本研究の分析では, 小麦の需要増加による水消費量への影響が最も大きかった. 小麦の需要に伴う用水増加量を合計すると, 流域全体で, およ そ 900 万 $\mathrm{m}^{3}$ となった. 用水増加量は, 河南, 山東, 寧夏回族自 治区の順に大きく, 増加量の大部分は省内の需要に起因して いる. トウモロコシの需要増加による用水量は小麦と比較すると 少ないが, 内蒙古自治区, 甘肃省, 寧夏回族自治区では, 流

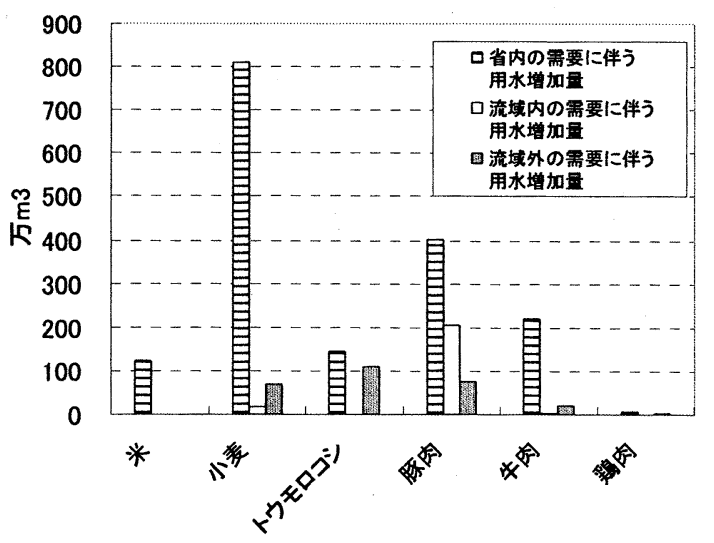

図-10 食料需要に伴う黄河流域の 用水増加量（所得増加率 $1 \%$ )

域外の需要による用水増加量が, 省内の需要に起因する用水増加量を上回っていた. トウモロコシについては, 需要の増 加による省内一の供給増加よりも, 流域外への供給増加に伴う用水量が大きかった. 肉類の需要増加による水消費量は, 豚肉の場合の用水増加量が 700 万 $\mathrm{m}^{3}$ で最大であった. このうち $30 \%$ 分が流域内の他省への供給増に伴う水消費量であ った. 黄河流域では, 上流と下流の用水利用の不均衡が指摘されている. 飼料換算でみた水消費量が大きい肉類の供給 依存関係は, 流域の水資源の平等な利用にも関連していると考えられる. しかし, 本研究では, 分析の前提とした食料の 移送経路を, 輸送モデルにより推計しており, 現実の詳細な供給経路の把握には至っていない. そのため, ここでの用水 消費に関する分析は, 個別の省間の水依存関係にまでは踏み込まず, 自省と流域内, 流域外の区分に基づいた計算を するにとどめた.

\section{謝辞}

本研究は, 大学共同利用機関法人: 人間文化研究機構·総合地球環境学研究所のプロジェクドある「近年の黄河の急 激な水循環変化とその意味するもの」と, 独立行政法人:科学技術振興機構·戦略的創造研究推進事業のプロジェクであ る「黄河流域の水利用·管理の高持続性化」の一環として行われたものである. 記して謝意を表す.

\section{参考文献}

1）穆月英·笠原浩三: 中国の食料消費ひ需要体系分析-都市部と農村部の比較を通して-, 農林業問題研究 3 月号, pp.219-224, 2001.

2) 中谷友樹: 中国における主要穀物の消費分布とその予測, LU/GECプロジェクト報告書(第 2 期最終報告書), 2001.

3) FAO:FAOSTAT, http://apps:fao.org/default.html

4) CIESIN: Columbia University, Center for International Earth Science Information Network, http://www.ciesin.org/data.html

5) 李徳水: 中国粮食供求調查与分析 2004, 中国統計出版社, 2004.

6) 中華人民共和国国家統計局:中国統計年鑑(各 年版), 中国統計出版社, 1997-2003.

7) 中華人民共和国農業部: 中国農業年鑑(各年版), 中国農業出版社, 1997-2003.

8）黒井尚志:『中国が 2600 億の卵を食べる日』 家の光協会, pp88, 1995.

9) Deaton and Muellbauer :An Almost Ideal Demand System, The American Economic Review, Vol. 70, 1980.

10） aiaiCHINA : 中国列車主要駅間距離表, http://www.china.co.jp/train_table/distance/index.html

11）石玉林:中国可持続発展水資源戦略研究報告集-第 4 巻, 中国水利水電出版社, pp.8-9, 2001.

12）中華人民共和国水利部:中国水資源公報, 2001. 